\title{
The Virus Causing Infectious Chlorosis in Banana (Musa sp.): A Review
}

\author{
Alan C. Antony ${ }^{1 *}$, O.M. Shaana ${ }^{2}$, N.U. Visakh ${ }^{3}$ and S. Haritharaj ${ }^{4}$ \\ ${ }^{1}$ Department of B. Vocprogrammes, SD College, Knajirappalli, M.G. University, \\ Kottayam, Kerala, India-686512 \\ ${ }^{2}$ Department of Agricultural Entomology, College of Agriculture, Padanakkad, Kerala \\ Agriculture University, Thrissur, Kerala, India-680656 \\ ${ }^{3}$ Department of Agricultural Entomology, College of Horticulture, Vellanikkara, Kerala \\ Agriculture University, Thrissur, Kerala, India-680656 \\ ${ }^{4}$ Agricultural Meteorology, KVK, Palakkad, Kerala Agricultural University, Thrissur, Kerala, \\ India-680656 \\ *Corresponding author
}

\section{A B S T R A C T}

\begin{tabular}{|l|}
\hline Key w o r d s \\
$\begin{array}{l}\text { Cucumber mosaic } \\
\text { virus, Serology, } \\
\text { Symptoms, Virus } \\
\text { Indexing, Vector, } \\
\text { Serology }\end{array}$ \\
\hline Article Info \\
\hline $\begin{array}{l}\text { Accepted: } \\
\text { 20 May } 2020 \\
\text { Available Online: } \\
\text { 10 June } 2020\end{array}$ \\
\hline \hline
\end{tabular}

Banana fruit crops are high in potassium, contain a high level of protein and dietary fiber which makes it world's most popular. The crop gives a maximum return to the farmers when good cultivation practices are followed, which include using diseasefree planting material. The crop is infected by several viruses viz., Banana bunchy top virus, Cucumber mosaic virus, Banana streak virus, Banana bract mosaic virus and Banana mild mosaic virus (Tripathi et al., 2016). Among these viruses, CMV causes a devastating effect on tissue culture banana plants. Various symptoms of CMV were reported under natural conditions like diamond-shaped discontinuous lesions, severe mosaic with extreme distortion and reduction of leaf lamina. KAU (2016) opined that infection due to CMV was observed in widely cultivated banana varieties in Kerala, such as Nendran, Palyankodan, Karpooravally and Poovan (Rasthali). Hence, virus indexing is a must to select healthy planting materials. Cucumber mosaic virus is transmitted through more than 60 species of aphids, including Aphis gossypii and Myzuspersicaeetc. The serological methods are widely used in the detection of Cucumber mosaic virus from the field.This review paper is focused on various aspects of novel detection methods of CMV infecting banana.

\section{Introduction}

Banana (Musa spp.) belongs to the genus Musa and family Musaceae of the order Zingiberales. The plant plays an amicable role in religious and cultural occasions, hence the crop has the name Kalpatharu (Plant of virtues). When banana is infected with virus it effects the production directly by reducing plant growth and yield. It causes yield losses of about 40-100 percent (Gambley and Thomas, 2001). Economically important 
viruses infecting banana are Banan bunchy top virus, Banana streak virus, Banana bract mosaic virus and Cucumber mosaic virus $(C M V)$. Banana viruses also have important indirect effects by restricting germplasm movement and predisposing plants to damage from other biotic and abiotic stress factors.

Cucumber mosaic virus was first reported simultaneously by Doolittle (1916) and Jagger(1916) in cucumber. This is an emerging viral disease in Kerala, India which causes leaf distortion, stunting of plant and yield reduction. Cucumber mosaic virus taxonomically grouped under family Bromovirdae, which contain five genera i.e., Alfamovirus, Ilavirus, Cucumovirus, Oleavirus and Bromovirus. It is important to understand the characteristics of each virus for effective control of viral diseases and the development of reliable virus detection methods. Biological, serological and molecular methods like Direct antigen coating enzyme-linked immunosorbent assay (DACELISA) and Reverse transcriptase-polymerase chain reaction (RT- PCR) are used to detect CMV from field. Antiserum production is an essential prerequisite for serological detection. Coat protein $(\mathrm{CP})$ region of CMV in a banana is sufficient enough to provide a reliable method for the detection of virus. This review article comprises the chronicle of biological, genomic, post-genomic and diagnostic studies of Cucumber mosaic virus.

\section{Genome organisation of Cucumber mosaic virus}

Members of the Bromoviridae family show significant diversity in their coat protein architectures. Alfamovirus having genome encapsidated in $19 \mathrm{~nm}$ wide bacilliform capsids (Hull et al., 1969). Bacilliform or quasi-spherical particles of varying sizes virus structure is observed in Oleavirus (Martelli and Grieco, 1997). Anulavirus (Gallitelli et al., 2005) and Ilarvirus (isometric labile ringspot virus) particles are quasi-spherical (Lister et al., 1972) and have sizes which depend on the type and length of packaged RNA. According to ICTV (2012), Cucumber mosaic virus causing infectious chlorosis in banana belongs to the family Bromoviridae. The entire genome consists of approximately $8 \mathrm{~kb}$ in length. Genomes comprise of three linear, positive sense ssRNAs with 5'terminal cap. The 3'termini are not polyadenylated but generally are highly conserved within an isolate or species. They are either tRNA-like and can be aminoacylated (genera Bromovirus and Cucumovirus). Major viral proteins associated with Bromoviridae family are enlisted in Table 1.

Cucumber mosaic virus is the type species of the genus Cucumovirus in the family Bromoviridae. It encloses three spherical particles, each approximately $28 \mathrm{~nm}$ in diameter. Subgenomic RNA (sgRNA) expresses a third nonstructural protein P2b. This helps in movement from cell-to-cell. Nonstructural movement protein (i.e., P3a, cell-to-cell MP) post-transcriptional gene silencing and RNA 3 represents the structural capsid protein or coat protein $(\mathrm{P} 3 \mathrm{~b}, \mathrm{CP})$ that is expressed via subgenomic RNA (i.e., RNA4 ) (Hull, 2009; Zitter and Murphy, 2009).

\section{Symptoms developed by the virus}

Downward bending of the petiole and leaf surface along with leaf reduction and severe epinasty, are the common symptoms of the virus in cucurbits. Plants infected at the early stage are severely stunted, leaves are malformed, and fruits are unmarketable because of obvious rugosity (Agrios, 2005; Zitikaite et al., 2011). Shoestring of upper leaf blades in tomatoas a distinctive symptom in the crop was reported by Sudhakar et al., (2006) and Aglave et al., (2007). Srivastava 
et al., (1992), Madhubala et al., (2005) and Bhadramurthy et al., (2009) recorded the symptoms caused by CMV in chrysanthemum, vanilla (Vanilla planifolia) and paprika (Capsicum annum L.) respectively.

The first signs of Cucumber mosaic virus infection in banana were noticed in Australia by Magee (1930). According to the external symptoms observed the disease was named infectious chlorosis, heart rot, virus sheath rot, cucumber mosaic and banana mosaic (Stover, 1972). Mosaic patterns or discontinuous linear streaking bands, extending from leaf margin to midrib are the characteristic symptoms of infectious chlorosis. Curling of leaves, rosette appearance of leaf arrangement and dead or dying suckersare noticed in advanced cases (Niblett et al., 1994; Rodoni et al., 1997; Sivaprasad et al., 2016; Tripathy, 2016). Banana mosaic is categorised as cosmopolitan and is found wherever bananas are grown. Even at a low titer of the virus, the whole leaf may become chlorotic due to decreased chlorophyll production and breakdown of chloroplasts (Dheepa and Paranjothi, 2010). The symptoms occurred sporadically and the majority of the leaves appeared healthy. The expression of symptoms can be influenced by virus strain and temperature (Hitchborn, 1956). Among all the strains of Cucumber mosaic virus infecting banana, heart rot strain causes significant losses, due to the rotting of inner leaves leading to the death of the plant (Lockhart, 2000).

In Kerala, the disease is considered as an emerging one and the symptoms were documented. The infected plants become dwarf and lag in growth. The infected plants mask the symptoms and act as a virus reservoir. But the plants become dwarf and lag in growth. Infected leaves produce parallel chlorotic streaks on younger leaves; later leaves become distorted, irregular wavy leaf margin along with necrotic tissues (KAU, 2016; Mujtaba, 2017). So far, no strains of the virus, causing heart rot are reported from Kerala, India (Antony, 2019).

\section{Distribution of the virus}

Cucumber mosaic virus is geographically widespread and having broad host range, including some annual crops in temperate zones, tropical regions and Mediterranean countries (Tomlinson, 1987). Cucumber mosaic virus (CMV) was first reported in detail on cucumber and other cucurbits but is now known to occur worldwide in most of the crops (Roosinck et al., 1999; Zitter and Murphy, 2009; Sokhandan-Bashir et al., 2012). Cucumber mosaic virus isolates were phylogenetically analysed and the subgroup I have subdivided into IA and IB. Among the subgroups, subgroup 1B of CMV is limited to Asia, and the other two subgroups (i.e., 1A and 2) are distributed worldwide (Sivaprasad et al., 2016).

In India, CMV occurrence has been reported in commercially grown flowers and spices such as chrysanthemum (Srivastava et al., 1992); carnation (Raj et al., 1993); black pepper (Sharma et al., 2001); and periwinkle (Catharanthus roseus) (Samad et al., 2008). Bhadramurthy (2008) reported that CMV causes mosaic symptoms in vanilla. The virus has been reported in Oxalis corymbosa in Aligarh, India (Sheikh et al., 2013).

According to Estelitta et al., (1996) and Mujtaba (2017), CMV is an emerging threat in banana farmers in Kerala, especially in the fields where, cucurbitaceous vegetables as intercrops in banana. In Kerala, infection of CMV was noticed in banana varieties such as Karpooravally, Nendran, Palayankodan, Peykunnan, Kosthabontha, Mottapoovan, Bhimkhel, Dhakhinsagar, Madhuraga, Rasthali and Musa ornate (KAU, 2016). 


\section{Detection of the virus}

So far, there is no protocol for the treatment of plant viral diseases, hence its detection is very crucial.As far there is no treatment protocol for plant viral diseases, detection of the virus causing infection is very crucial. The techniques applied for the diagnosis of plant viral diseases include biological, serological and molecular means (Lopez et al., 2003). When the sample size to be tested is large, double antibody sandwich-enzyme linked immunosorbent assay is widely used. Virus detection methods have upgraded greatly in recent years with the development diagnostic techniques that can be applied directly in the field.

Nucleic acid probes methods, RT-PCR and ELISA were used for the differentiation of CMV isolates in chrysanthemum (Srivastava et al., 1992), carnation (Raj et al., 1993), banana (Kiranmai et al., 1996), geranium (Verma et al., 2004), gladiolus, pepper and vanilla (Madhubala et al., 2005), and anthurium (Miura et al., 2013).

\section{Molecular diagnosis}

Molecular techniques are powerful, sensitive and popular methods used for detection of plant viruses and viroids (Hu et al., 1995).It is widely used by researchers in scientific field such as molecular cloning, gene manipulation, gene expression analysis, sequencing, and mutagenesis (Lundberg et al., 1991; Makkouk and Kumari, 2006; Verkuil et al., 2008). RTPCR is used to detect RNA viruses like CMV, which includes reverse transcription of RNA followed by normal PCR (Choi et al., 1999; Ghangal et al., 2009; Jeong et al., 2014).

This method was well-known to detect seedborne infection and seed transmission frequency of CMV in pepper seed (Ali and Kobayashi, 2010). The RT-PCR in turn is used for genomic and post genomic studies of RNA viruses. Amplification of CP (using gene specific primers) of CMV infecting banana and other crops at $\sim 700$ bphas reported (Zein and Miyatake, 2009; Ali et al., 2012; Khan et al., 2012; El- Borollosy and Hassan, 2014; Shetti et al., 2014; Antony, 2019). Sudhakar et al., (2006), detected virus infecting tomato by RT-PCR and restriction fragment length polymorphism analysis (RFLP).Molecular detection has standardised for CMV infecting Oxalis corymbosa, a common weed of banana orchads(Sheikh et al., 2013). Southern hybridisation test is is also used for sensitive detection of CMV from gladiolus leaf and corms (Pandey, 2015).

\section{Molecular detection of virus variability}

Deoxy ribonucleic acid sequencing is the process of determining the molecular sequence of particular gene, which determines the order of the four nitrogen bases viz., adenine, guanine, cytosine, and thymine.The sequence of the CP gene of the CMV from paprika (Capsicum annuum L.) contained a single open reading frame of 657 nucleotides potentially coding for 218 amino acids (Bhadramurthy et al., 2009).

Indian isolates of CMV, infecting various crops were sequenced and found out its homology with subgroup II of CMV (Kumar et al., 2005; Kumari et al., 2013). High sequence identities and evolutionary tie in coat protein gene has been observed with CMV isolate fromKerala (Mujtaba, 2017). Serological detection of BSV has been problematic due to serological and genomic heterogeneity of the virus isolates (Selvarajan et al., 2016). 
Table.1 Details of viral protein encoded in Bromoviridae

\begin{tabular}{|l|l|l|l|}
\hline Protein & Size $(\mathbf{k D a})$ & mRNA & Function \\
\hline 1a & $102.7-125.8$ & RNA 1 & Helicase, Methyltransferase \\
\hline 2a & $78.9-96.7$ & RNA 2 & Replicase \\
\hline 3a & $30.5-36.5$ & RNA 3 & Cell to cell movement \\
\hline Coat protein & $19.8-26.2$ & Sub-genomic RNA- 4 & Encapsidation, intercellular movement \\
\hline
\end{tabular}

Table.2 Major plant virus coat protein expressed through in vivo protein expression system

\begin{tabular}{|c|c|c|}
\hline Expressed gene & Expression system used & Reference \\
\hline $\begin{array}{l}\text { Cucumber mosaic virus } \\
\text { (Cucumber isolate) coat / capsid } \\
\text { protein (CP) }\end{array}$ & pET21a/E. coli strain Rosetta & Rostami et al., (2014) \\
\hline Tobacco streak mosaic virus $\mathbf{C P}$ & pRSET- C/ E. coli (DE3) BL21 & Gulati et al., (2016) \\
\hline Alfalfa mosaic virus $\mathbf{C P}$ & E. coli/pTrcHisB & Yusibov et al., (1996) \\
\hline $\begin{array}{l}\text { Pepper vein banding virus encoded } \\
\text { protein }\end{array}$ & pRSETC/E.coli(DE3)BL21 & Sabharwal (2017) \\
\hline Cardamom mosaic virus $\mathbf{C P}$ & pProEXHTb/E. coli & Jacob and Usha (2002) \\
\hline Banana bract mosaic virus $\mathbf{C P}$ & pMAL-c2/E.coli (DE3)BL21 & Wanitchakorn et al., (1997) \\
\hline $\begin{array}{l}\text { Grapevine leafroll associated } \\
\text { closterovirus-3 CP }\end{array}$ & pRSET-C/E. coli (DE3)BL21 & Ling et al., (2000) \\
\hline Sugarcane streak mosaic virus $\mathbf{C P}$ & pRSET-A/E. coli (DE3)BL21 & Hema et al., 2003 \\
\hline Prune dwarf virus $\mathbf{C P}$ & pRSET/Epicurian coli BL 21-Gold & Jawdah et al., (2004) \\
\hline Nipah virus matrix protein & $\begin{array}{l}\text { Spodopterafrugiperda- } 9 \text { (sf- 9) cell line } \\
\text { using baculovirus expression system }\end{array}$ & Dezfooli et al., (2016) \\
\hline $\begin{array}{l}\text { Viral associated protein of } \\
\text { Banana streak virus }\end{array}$ & E. coli based expression system & Selvarajan et al., (2016) \\
\hline Papaya ringspot virus $\mathbf{C P}$ & pRSET-B/E.coli DH5 $\alpha$ & Valekunja et al., 2016 \\
\hline Banana bunchytop virus $\mathrm{CP}$ & pET28a $(+) / E$. coli BL21 & Arumugam et al., (2017) \\
\hline Grapevine fanleaf virus $\mathrm{CP}$ & pET28a/ E. coli (DE3)BL21 & Shibaei et al., 2018 \\
\hline \multirow[t]{5}{*}{ Cucumber mosaic virus $\mathbf{C P}$} & pQE30/E. coli $\mathrm{M} 15$ & Khan et al., (2012) \\
\hline & pRSET-B/E. coli DH5 $\alpha$ & Pandey (2015) \\
\hline & pET21- d(+)/E. coli (DE3)BL21 & Kim et al., (2016) \\
\hline & pET21a/E. colistarin Rosetta & Koolivand et al., (2017) \\
\hline & pRSET-C/E. coli (DE3) BL21 & Antony (2019) \\
\hline
\end{tabular}




\section{Serological diagnosis}

Detection of plant viruses based on symptoms are of limited value in certain condition. So, identification of the viruses by serological methods will be of more accurate, reliable, less time consuming (Dheepa and Paranjothi, 2010).Enzyme Linked Immuno-Sorbent Assay has been successfully used for the large scale detection of plant viruses including Banana bunchy top virus, Banana bract mosaic virus and Cucumber mosaic virus(Clark and Adams, 1977; Clark, 1981; Espino et al., 1989; Geering and Thomas 1996; Kiranmai et al., 1996; Ling et al., 2000; Shetti et al., 2014). Several other serological methods are available for the detection of plant viruses like lateral flow test and Immunocapture-Reverse TranscriptasePolymerase Chain reaction (IC- RT- PCR) (Komorowska and Malinowski, 2009; Zein and Miyatake, 2009).

Different serological assays used for detection of CMV are immunodiffusion (Scott, 1968), tube and ring precipitin tests (Mink et al., 1975), western blotting (Towbin et al., 1979), SDS immunodiffusion in agarose gel (Purcifull et al., 1981). Cucumber mosaic virus isolates are detected using Triple Antibody Sandwich Enzyme Linked ImmuneSorbent Assay (TAS-ELISA) and IC-RT-PCR (Yu et al., 2005). $\mathrm{Wu}$ and $\mathrm{Su}$ (1990) developed plate-trapped antigen (PTA) ELISA using monoclonal antibodies, to detect BBTV. Agindotan et al., (2003) reported the higher sensitivity of immune- electron microscopy (IEM) for detecting Banana streak virus (BSV). Hosseinzadeh et al., (2012) detected CMV by DAS- ELISA in 10 crops viz., tomato, pea, watermelon, tobacco, broad bean, soybean, squash, eggplant, cucumber and lettuce. Among these, the highest and the lowest CMV infection was associated with watermelon (62.44 per cent) and lettuce (Zero per cent), respectively.
Detection of CMV has been done using antisera developed against recombinant coat protein $(\mathrm{rCP})$ of the virus (Khan et al., 2012; EI- Borollosy and Hassan, 2014).

\section{Protein expression and purification}

High quality viral antibody with less contamination of host proteins is an essential pre requisite for virus indexing. Hence, Hochuli et al., (1987); Chow (2006); Hartley (2006) standardized the protocols for cloning of virus coat protein gene in expression vectors and purification of recombinant protein. Through this method, virus coat protein with less contamination of host proteins can be prepared and thus, the same can be used for antiserumproduction.

Expression of plant viral coat protein is highly preferred by cell based (in vivo) expression system, which include suitable expression host and vector (Nettleship et al., 2010). E. coli BL21 (DE3) pLysS is the most commonly used expression host, which is a derivative of $E$. coli BL21(DE3). DE3 is an arrangement of T7 RNA Polymerase gene, under the control of LacUV 5 promotor on a phage genome and pLysS is a plasmid that encodes T7 lysozyme gene. The T7 RNA lysozyme bind to T7 RNA polymerase gene, and block the induction until the addition of IPTG. After the addition of IPTG, number of T7 RNA polymerase gene increases and overcomes the inhibition of LysS (Rosano and Ceccarelli, 2014). Major plant viral coat proteins expressed through in vivo system of protein expression are enlisted in Table 2.

In conclusion, infectious chlorosis caused by CMV has attained a serious status in most of the banana growing states of India. Realizing the potential threats of cucumber mosaic disease of banana, it is feared that in future Indian banana growing areas might be highly affected by this disease (Khan et al., 2011). 
Aim of this paper illustrates immunedetection and cloning of $\mathrm{CP}$ gene of field isolates to correctly diagnose the disease and to assess similarity or variability among isolates of CMV infecting banana. This paper compares the conventional partial purification of virus over, recombinant coat protein production. During high speed ultracentrifugation, plant proteins are also get contaminated with virus coat protein, in turn the same will contaminate the antiserum, which often led to false result during immune detection of the virus. But recombinant coat protein mediated antiserum, as it doesn't contain plant protein, detection the virus with maximum efficiency.

\section{References}

Agindotan, B. O., Thottappilly, G., Uwaifo, A., and Winter, S. 2003. Production of monoclonal and polyclonal antibodies against a Nigerian isolate of banana streak virus. Afr. J. Biotechnol. 2:171-178.

Aglave, B. A., Krishnareddy, M., Patil, F. S., and Andhale, M. S. 2007. Molecular identification of a virus causing banana chlorosis disease from Marathwada region. Int. J. Biotechnol. Biochem. 3(1):13-24.

Agrios, G. N. 2005. Plant Pathology (5th Ed.). Elsevier Academic Press, San Diego, 922p. Ali, A. and

Ali, S., Akhtar, M., Singh, K. S., and Naqvi, Q. A. 2012. RT-PCR and CP gene based molecular characterization of a cucumber mosaic cucumovirus from Aligarh, UP, India. Agric. Sci. 3(08): 971.

Antony, A. C. 2019. Devolopment of recombinant coat protein for immunodetection of Cucumber mosaic virus infecting banana. M.Sc. (Ag.) thesis, Kerala Agricultural University, Thrissur, $84 \mathrm{p}$.

Arumugam, C., Klaimughilan, K., and Kathithachalam, A. 2017. Banana bunchy top viral coat protein (cp) gene expression studies at molecular level in hill banana cv. Sirumalai (AAB). Int. J. Curr. Microbiol. Appl. Sci. 6(6): 398-411.

Bhadramurthy, V. 2008. Identification, molecular characterization and development of diagnostics for the viruses associated with vanilla (Vanilla planifolia Andrews) Ph. D thesis, Mangalore University, Mangalore, 88p.

Bhadramurthy, V., George, A., Bhat, A. I., and Shiva, K. N. 2009. Coat protein gene sequence studies suggest that Cucumber mosaic virus infecting paprika (Capsicum annuum L.) in India belongs to subgroup IB. Arch. Phytopathol. Plant Protect. 42(9):857-863.

Choi, S. K., Choi, J. K., Park, W. M., and Ryu, K. H. 1999.RT-PCR detection and identification of three species of Cucumoviruses with a genus-specific single pair of primers. J. Virol. Methods. 83(1-2): 67-73.

Chow, M. K., Amin, A. A., Fulton, K. F., Fernando, T., Kamau, L., Batty, C., Louca, M., Ho, S., Whisstock, J. C., Bottomley, S. P., and Buckle, A. M. 2006. The REFOLD database: a tool for the optimization of protein expression and refolding. Nucleic Acids Res. 34(1): 207212.

Clark, M. F. 1981. Immunosorbent assays in Plant Pathology. Annu. Rev. Phytopathol. 19(1):83-106.

Clark, M. F. and Adams, A. N. 1977. Characteristics of the micro plate method of enzyme-linked immunosorbent assay for the detection of plant viruses. J. Gen. Virol. 34(3): 475-483.

Dezfooli, M. S., Tan, W. S., Tey, B. T., Ooi, C. W., and Hussain, S. A. 2016.Expression and purification of the matrix protein of Nipah virus in baculovirus insect cell system. Biotechnol. Prog. 32(1): 171-177.

Dheepa, R. and Paranjothi, S. 2010. Transmission of Cucumber mosaic virus infecting banana by aphid and mechanical methods. Emirates J. Food Agric. 28(8)117-129.

Doolittle, S. P. 1916. A new infectious mosaic disease of cucumber. Phytopathol. 6(2): 
145- 147.

Espino, T. M., Exconde, S. B., Zipagan, F. B., Maroon, M. C. M., and Espino, R. R. C. 1989. Production of monoclonal antibodies for diagnosis of banana bunchy top virus. Philipp. Agric. 72:473-485.

Estelitta, S., Radhakrishnan, T.C., and Paul, T.S. 1996.Infectious chlorosis disease of banana in Kerala. Infomusa. 5(2): 25-26.

Gambley, C. F. and Thomas J. E. 2001.Molecular characterisation of Banana mildmosaic virus, a new filamentous virus in Musa spp. Arch. Virol. 146(7): 1369- 1379.

Geering, A. D. W. and Thomas, J. E. 1996.A comparison of four serological tests for the detection of banana bunchy top virus in banana. Aust. J. Agric. Res. 47(3): 403412.

Ghangal, R., Raghuvanshi, S., and Sharma, P. C. 2009.Isolation of good quality RNA from a medicinal plant seabuckthorn, rich in secondary metabolites. Plant Physiol. Biochem. 47(11-12): 1113-1115.

Gulati, A., Alapati, K., Murthy, A., Savithri, H. S., and Murthy, M. R. N. 2016. Structural studies on tobacco streak virus coat protein: Insights into the pleomorphic nature of ilarviruses. J. Struct. Biol. 193(2): 95-105.

Hartley, J. L. 2006. Cloning technologies for protein expression and purification. Curr.Opinion Biotechnol. 17(4): 359-366.

Hema, M., Kirthi, N., Sreenivasulu, P., and Savithri, H. S. 2003. Development of recombinant coat protein antibody based IC-RT-PCR for detection and discrimination of Sugarcane streak mosaic virus isolates from Southern India. Arch. Virol. 148 (6): 1185-1193.

Hitchborn, J. H. 1956. The effect of temperature on infection with strains of cucumber mosaic virus. bAnnals Applied Biol.44(4): 590-598.

Hochuli, E., Dobeli, H., and Schacher, A. 1987.New metal chelate adsorbent selective for proteins and peptides containing neighbouring histidine residues. J. Chromatography. 411: 177-
184.

Hosseinzadeh, H., Nasrollanejad, S., and Khateri, H. 2012. First report of cucumber mosaic virus subgroups 1 and 2 on soybean, pea, and eggplant in Iran. Acta Virol. 56(2): 145-148.

Hu, J. S., Li, H. P., Barry. K., and Wang, M. 1995. Comparison of dot blot ELISA and RT-PCR assays for detection of two cucumber mosaic virus isolates infecting banana in Hawai. Plant Dis. 79: 902-906.

Hull, R. 2009. Comparative Plant Virology (2nd Ed.).Academic press. China. 255p.

ICTV [International Committee on Taxonomy of Viruses]. 2012. Ninth Report on Bromoviridae 2012. International Committee on Taxonomy of Viruses. 976p.

Jacob, T. and Usha, R. 2002. Expression of Cardamom mosaic virus coat protein in Escherichia coli and its assembly into filamentous aggregates. Virus Res. 86(1): 133-141.

Jagger, I. C. 1916.Experiments with the cucumber mosaic disease.Phytopathol. 6(2): 149- 151.

Jawdah, A., Sobh, H., Cordahi, N., Kawtharani, H., Nemer, G., Maxwell, D. P., and Nakhla, M. K. 2004.Immunodiagnosis of Prune dwarf virus using antiserum produced to its recombinant coat protein. J. Virol. Method 121(1): 31- 38.

Jeong, J. J., Ju, H. J., and Noh, J. 2014. A review of detection methods for the plant viruses. Res. Plant Dis. 20(3): 173-181.

KAU [Kerala Agricultural University] 2016. Package of Practices Recommendations: Crops (15th Ed.). Kerala Agricultural University, Thrissur, 392p.

Khan, S., Jan A. T., Aquil, B., Mohd Q., and Haq R. 2011. Regular article coat protein gene based characterization of Cucumber mosaic virus isolates infecting banana in India. J. Phytol. 3(2): 94-101.

Khan, S., Jan, A. T., Mandal, B., and Haq, Q. M. R. 2012. Immunodiagnostics of Cucumber mosaic virus using antisera developed against recombinant coat protein. Arch. Phytopathol. Plant Protect. 
45(5): 561-569.

Kim, H. S., Kim, D. W., and Jung, Y. T. 2016.Development of serological procedures for sensitive, rapid detection of Cucumber mosaic virus in Lilium. Hortic. Environ. Biotechnol. 57(6): 633639.

Kiranmai, G., Sreenivasulu, P., and Nayudu, M. V. 1996. Comparison of three different tests for detection of cucumber mosaic cucumovirus in banana (Musa paradisiaca). Curr. Sci. 32: 764-767.

Kobayashi, M. 2010. Seed transmission of Cucumber mosaic virus in pepper. J. Virol. Methods. 163(2): 234-237.

Komorowska, B. and Malinowski, T. 2009. Attempts to produce antiserum against Apple stem pitting virus coat protein (ASPV-CP) obtained in prokaryotic and eukaryotic expression systems. J. Fruit Ornamental Plant Res. 17(2):21-30.

Koolivand, D., Sokhandan Bashir, N., and Rostami, A. 2017.Preparation of polyclonal antibody against recombinant coat protein of Cucumber mosaic virus isolate B13. J. Crop Protect. 6(1): 25-34.

Kumar, S., Srivastava, A., and Raj, S. K. 2005. Molecular detection of Cucumber mosaic virus in chrysanthemum cultivars. Acta Phytopathol. Entomol. Hung. 40(3-4): 205-211.

Kumari, R., Bhardwaj, P., Singh, L., Zaidi, A. A., and Hallan, V. 2013. Biological and molecular characterization of Cucumber mosaic virus subgroup II isolate causing severe mosaic in cucumber. Indian $\mathrm{J}$. Virol. 24(1): 27-34.

Ling, K. S., Zhu, H. Y., Jiang, Z. Y., and Gonsalves, D. 2000. Effective application of DAS-ELISA for detection of grapevine leafroll associated closterovirus-3 using a polyclonal antiserum developed from recombinant coat protein. Eur. J. Plant Pathol. 106(4): 301-309.

Lockhart, B. E. 2000. Virus diseases of Musa in Africa: Epidemiology, detection and control. In: Craenen, K., Ortiz, R., Karamura, E.B., and Vuylsteke, D. (ed.), 1 International Conference on Banana: 1
International Conference on Banana and Plantain for Africa. ActaHorticulturea, Uganda, pp. 355-359.

López, M. M., Bertolini, E., Olmos, A., Caruso, P., Gorris, M. T., Llop, P., Penyalver, R. and Cambra, M. 2003. Innovative tools for detection of plant pathogenic viruses and bacteria. Int. Microbiol. 6(4): 233243.

Lundberg, K. S., Shoemaker, D. D., Adams, M. W., Short, J. M., Sorge, J. A., and Mathur, E. J. 1991. High-fidelity amplification using a thermostable DNA polymerase isolated from Pyrococcus furiosus. Gene 108(1): 1-6.

Madhubala, R., Bhadramurthy, V., Bhat, A. I., Hareesh, P. S., Retheesh, S. T., and Bhai, R. S. 2005. Occurrence of Cucumber mosaic virus on vanilla (Vanilla planifolia Andrews) in India. J. Biosci. 30(3): 39-350.

Magee, C. J. 1930. A new virus disease of Bananas. Agric. Gaz. New South Wales. 41(12).140-156.

Makkouk, K. and Kumari, S. 2006. Molecular diagnosis of plant viruses. Arab J. Plant Protec. 24(2): 135-138.

Mink, G. I., Lizuka, N., and Kiriyama, K. 1975. Some cucumber mosaic virus antisera contain antibodies specific for both peanut stunt virus and chrysanthemum mild mottle virus. Phytopathol. 65: 65-68.

Miura, N. D. S., Beriam, L. O., and Rivas, E.B. 2013. Detection of Cucumber mosaic virus in commercial anthurium crops and genotypes evaluation. Hortic. Brasileira. 31(2): 322-327.

Mujtaba, A. V. 2017. Molecular characterization of virus causing infectious chlorosis disease of banana. Ph.D. thesis, Kerala Agricultural University, Thrissur, $136 \mathrm{p}$.

Niblett, C. L., Pappu, S. S., Bird, J., and Lastra, R. 1994. Compendium of tropical fruit disease- Infectious chlorosis, mosaic and heart rot. APS Press, St Paul, Minnesota, $84 \mathrm{p}$.

Pandey, M. 2015. Immunodiagnosis of Cucumber mosaic virus (CMV), with 
polyclonal antibodies raised against coat protein (CP) gene of the virus. M.Sc. (Ag.) thesis, University of Agricultural Sciences GKVK, Bengaluru, 88 p.

Purcifull, D. E., Christie, S. R. and Lima, J. A. A. 1981. Detection of four isometric plant viruses in sodium dodecyl sulfate immunodiffusion tests. Phytopathol. 71(11): 1221-1224.

Raj, S. K., Srivastava, K. M., and Singh, B. P. 1993.Natural infection of cucumber mosaic virus on Dianthus barbatus in India. Plant Pathol. 42(5): 811-813.

Rodoni, B. C., Ahlawat, Y. S., Varma, A., Dale, J. L., and Harding, R.M. 1997. Identification and characterization of banana bract mosaic virus in India. Plant Dis. 81(6): 669-672.

Rosano, G. L. and Ceccarelli, E. A. 2014. Recombinant protein expression in Escherichia coli: advances and challenges. Frontiers Microbiol.5: 172.

Rostami, A., Bashir, N. S., Pirniakan, P., and Masoudi, N. 2014. Expression of Cucumber mosaic virus coat protein and its assembly into virus like particles. Biotechnol. Health Sci. 1(3): 180.

Sabharwal P. 2017. Molecular insight in to the structure and function of Pepper vein banding virus encoded proteins and endocytic uptake pathway of virus- like particles in to mammalian cells. Ph.D. thesis, Indian Institute of Science, Bangalore, 115p.

Samad, A., Ajayakumar, P. V., Gupta, M. K., Shukla, A. K., Darokar, M. P., Somkuwar, B., and Alam, M. 2008. Natural infection of periwinkle (Catharanthus roseus) with Cucumber mosaic virus, subgroup IB. Aust. Plant Dis. Notes. 3(1): 30-34.

Scott, H.A. 1968. Serological behavior of Cucumber mosaic virus (strain Y) and the virus protein. Virology 34(1): 79-90.

Selvarajan, R., Balasubramanian, V., and Gayathrie, T. 2016. Highly efficient immunodiagnosis of episomal Banana streak mosaic virus using polyclonal antibodies raised against recombinant viral- associated protein. J. Phytopathol. 164(7-8): 497-508.

Sharma, Y. R., Kiranmani, G., Sreenivasulu P., Anandaraj M., Hema, M., Venkatramana M, Murthy, A. K., and Reddy, V. R. 2001. Partial characterization and identification of a virus associated with stunt disease of black pepper (Piper nigrum) in South India. Curr. Sci. 80: 459 62.

Sheikh, M., Naqvi, Q. A., and Mahmood, I. 2013. Molecular detection of an isolate of Cucumber mosaic virus infecting Oxalis corymbosa, in Aligarh, India. Arch. Phytopathol. Plant Protec. 46(15): 18161820.

Shetti, P., Peter, A., and Jingade, P. 2014. Serological and molecular detection of an isolate of Cucumber Mosaic Virus infecting cucumber (Cucumis sativus) and cloning of its coat protein gene. J. Biochem. Technol. 3(5): 198-202.

Shibaei, N., Majidi, J., Sokhandan Bashir, N., Karkhaneh, A. A., and Razavi, K. 2018. Production and partial purification of the Grapevine fanleaf virus coat protein 42 polyclonal antibody against inclusion body expressed in Escherichia coli. Iranian J. Biotechnol. 16(4): 303-310.

Sivaprasad, Y., Mendez, K., Garrido, P., Serrano, S., and Garrido, A. 2016. Serological and molecular identification of cucumber mosaic virus (CMV) infecting banana crops in Ecuador. Revista Científica Ecuatoriana. 24(4): 1722.

Sokhandan Bashir, Nematollahi, S., N., Rakhshandehroo, F., and Zamanizadeh, H.R. 2012. Phylogenetic analysis of new isolates of Cucumber mosaic virus from Iran on the basis of different genomic regions. Plant Pathol. J. 28(4): 381-389.

Srivastava K, M., Raj, S., K., and Singh, B. P. 1992, Properties of a Cucumber mosaic virus strain naturally infecting chrysanthemum in India. Plant Dis. 76(4): 474- 491.

Stover, R.H. 1972. Banana, plantain and abaca diseases. Commonwealth Mycological 
Institute, Kew, UK, 316p.

Sudhakar, N., Nagendra-Prasad, D., Mohan, N., and Murugesan, K. 2006.First report of Cucumber mosaic virus subgroup II infecting Lycopersicon esculentum in India. Plant Dis. 90(11): 1457-1457.

Tomlinson, J. A. 1987. Epidemiology and control of virus diseases of vegetables. Ann. Appl. Biol. 110(3): 661-681.

Towbin, H., Staehelin, T., and Gordon, J. 1979. Electrophoretic transfer of proteins from polyacrylamide gels to nitrocellulose sheets: procedure and some applications. Proc. National Acad. Sci. 76(9): 43504354.

Tripathi, S., Patil, B. L. and Verma, R. 2016.Viral diseases of banana and their management. In: Kumar, R., Manchey, G., Basavaprabhu, P. L., Mariya, P., and Stoyanova, I. (ed.), Plant viruses: Evolution and management. Springer, Singapore, pp. 289-308.

Valekunja, R. B., Kamakoti, V., Peter, A., Phadnis, S., Prasad, S., and Nagaraj, V.J. 2016.The detection of papaya ringspot virus coat protein using an electrochemical immunosensor. Anal. Methods 8(48): 8534-8541.

Verkuil, E., van Belkum, A. and Hays, J.P., 2008. Taq and Other Thermostable DNA Polymerases. Principles and Technical Aspects PCR Amplification. Springer. Netherlands. 103-118p.

Verma, N., Singh, A. K., Singh, L., Kulshreshtha, S., Raikhy, G., Hallan, V.,
Ram, R., and Zaidi, A. A. 2004. Occurrence of cucumber mosaic virus in Gerbera jamesonii in India. Plant Dis. 88(10): 1161-1161.

Wanitchakorn, R., Harding, R. M., and Dale, J. L. 1997.Banana bunchy top virus DNA3encodes the viral coat protein. Arch. Virol. 142(8): 1673-1680.

$\mathrm{Wu}, \mathrm{R}$. Y. and Su, H. J. 1990.Purification and characterization of banana bunchy top virus. J. Phytopathol. 128(2): 153-160.

Yu, C., Wu, J., and Zhou, X. 2005. Detection and subgrouping of Cucumber mosaic virus isolates by TAS-ELISA and immunocapture RT-PCR. J. Virol. Methods.123: 15561.

Yusibov, V., Kumar, A., North, A., Johnson, J. E., and Loesch-Fries, L. S. 1996. Purification, characterization, assembly and crystallization of assembled alfalfa mosaic virus coat protein expressed in Escherichia coli. J. Gen. Virol. 77(4): 567-573.

Zein, H.S. and Miyatake, K. 2009.Development of rapid, specific and sensitive detection of Cucumber mosaic virus. African J. Biotechnol. 8(5): 48- 53.

Zitikaite, I., Staniulis, J., Urbanaviciene, L., and Zizyte, M. 2011. Cucumber mosaic virus identification in pumpkin plants. Zemdirbyste Agric. 98(4): 421-6.

Zitter, T. A. and Murphy, J.F. 2009.Cucumber mosaic virus. American J. Phytopathol. 75(6): 34- 45.

\section{How to cite this article:}

Alan C. Antony, O.M. Shaana, N.U. Visakh and Haritharaj, S. 2020. The Virus Causing Infectious Chlorosis in Banana (Musa sp.): A Review. Int.J.Curr.Microbiol.App.Sci. 9(06): 2681-2691. doi: https://doi.org/10.20546/ijcmas.2020.906.326 